\title{
From vacant land to urban fallows: a permacultural approach to wasted land in cities and suburbs
}

\author{
Alex Korsunsky ${ }^{1}$ \\ Vanderbilt University, USA
}

\begin{abstract}
While vacant land in cities has long been considered a sign of decline, a growing literature now suggests that such land can serve valuable social and ecological functions. In this article, I argue that such approaches advocated to date, while beneficial, operate within a New Urbanist framework that is essentially concerned with filling in vacant land with new 'green' projects. Unfortunately, such approaches are limited by a conceptualization of the city that treats inner city vacant lots as paradigmatic and makes invisible the systematic creation of functionally vacant land through zoning and building practices in low-density residential areas. Inspired by degrowth scholarship, I suggest that permaculture may provide the basis for an alternative approach based in the concept of fallowing more suited to the full range of vacant land present in American cities and suburbs. I explore the implications of such an approach through the practice of two permaculture-inspired intentional communities in the Pacific Northwest.
\end{abstract}

Key words: vacant land, permaculture, New Urbanism, intentional communities, commons, degrowth

\section{Résumé}

Bien que les terrains vacants dans les villes aient longtemps été considérés comme un signe de déclin, des études scientifiques suggèrent que ces terrains peuvent remplir des fonctions sociales et écologiques précieuses. Dans cet article, je soutiens que les approches préconisées à ce jour, bien que bénéfiques, s'inscrivent dans un nouveau cadre urbaniste (New Urbanist framework), qui consiste essentiellement à combler les terrains vacants par de nouveaux projets «verts». Malheureusement, ces approches sont limitées par une conceptualisation de la ville qui traite les terrains vacants du centre-ville comme un paradigme et ignore la création systématique de terrains vacants au moyen de pratiques de zonage et de construction dans des zones résidentielles à faible densité. Inspiré par la recherche sur la décroissance, je suggère que la permaculture pourrait servir de base à une approche alternative basée sur le concept de jachère plus adapté à la gamme complète de terrains vacants présents dans les villes et les banlieues américaines. J'explore les implications d'une telle approche à travers la pratique de deux communautés intentionnelles inspirées par la permaculture dans le nord-ouest du Pacifique.

Mots-clés: terrain vacant, permaculture, nouvel urbanisme, communautés intentionnelles, commun, décroissance

\section{Resumen}

Aunque las tierras vacantes en la ciudad han sido consideradas una indicación de declino, una nueva literatura sugiere que estas tierras puedan servir funciones sociales y ecológicas valorables. En este artículo, propongo que, a pesar de los beneficios de estas estrategias, operan dentro de una perspectiva de Nuevo Urbanismo que está enfocada en llenar tierras vacantes con nuevos proyectos 'verdes'. Desafortunadamente, están limitadas por una conceptualización de la ciudad que trata con los centros de las ciudades como un paradigma, y hace invisible la creación sistemática de tierras efectivamente vacantes por medio de zonación y prácticas de construcción en áreas residenciales de densidades bajas. Inspirado por la escolaridad sobre decrecimiento, sugiero que la permacultura pueda ofrecer la fundación por un abordo alternativo basado en el concepto del barbecho más

\footnotetext{
${ }^{1}$ Alex Korsunsky, PhD student, Department of Anthropology, Vanderbilt University, Nashville, TN 37235, USA. Email: alexander.s.korsunsky "at" vanderbilt.edu. The author would like to gratefully acknowledge the support and enthusiasm of John Janusek and Norbert Ross in developing this paper, as well as the kind and constructive comments of two anonymous reviewers. Special and very heartfelt thanks to everyone at Kailash Ecovillage and at Songaia Cohousing Community, particularly to Ole and Maitri, and to Brian, Helen, Patricia, and Nancy.
} 
apropiado a la variedad de tierras vacantes en ciudades y suburbios estadounidenses. Exploro las implicaciones de este abordo por las prácticas de dos comunidades intencionales inspiradas por la permacultura en la región noroeste de los EE.UU.

Palabras clave: tierra vacante, permacultura, Nuevo Urbanismo, comunidades intencionales, bienes comunes, decrecimiento

\section{Introduction}

While cities are commonly imagined as separate from and opposed to nature, urban political ecologists point to the myriad ways in which cities are inseparably entangled with environments both within and far beyond their boundaries, and dependent on ecological systems for their survival (Cronon 1991; Gandy 2003; Kelman 2003; Rosen and Tarr 1994). Rather than spaces outside of nature, cities should be conceived and designed as ecosystems that serve integrated human and environmental purposes. The urban design philosophy broadly referred to as New Urbanism offers an influential slate of practical solutions responding to urban ecology's critique, including greater density, mixed uses, and the rejection of car-centric design ("The Charter of the New Urbanism," n.d.; Duany, Plater-Zyberk and Speck 2000; Jackson 1985; Kunstler 1993). Unfortunately, however, such plans for 'sustainable' or 'smart' development are often expensive, potentially serving processes and agents of gentrification, and perpetuating spatial segregation and environmental inequality (Gray-O'Connor 2009; Pyatok 2000; for a cautiously optimistic perspective, see Bohl 2000).

Underlying these problems is the fact that New Urbanist design solutions are offered within an implicit ecomodernist framework which proposes that growth can be decoupled from environmental impact, and is therefore predisposed to solutions that continue to invite or require new development (Asafu-Adjaye et al. 2015). However, decoupling is at best theoretical and quite possibly a fantasy (Ward et al. 2016). Advocates of degrowth - who observe that accelerating rates of consumption cannot continue indefinitely - therefore argue that citizens of wealthy countries must adopt more modest lifestyles, and that strong communities can enable us to achieve this aim without sacrificing quality of life (LeBlanc 2017; Lockyer 2017; Paulson 2017). That is, contra the ecomodernists, degrowth prioritizes social and cultural solutions that enable us to meet human needs over the sort of solutions that require new development, 'smart' or otherwise. This perspective suggests that, notwithstanding New Urbanism's merits, sustainable development may not be adequate to preserve a livable world, and that we must seek out strategies that do not rely on growth.

If cities are not only analogous to, but in literal fact are, living ecosystems, systems of design and analysis focused only on the things that people build are not enough. We need "buildings like trees, alive to their surroundings and inhabitants, and cities like forests, in which nature and design create a living, breathing habitat" (McDonough and Braungart 2002). Permaculture - a design philosophy that originated in agroecology, and is rooted in the principle that human designs should mimic natural systems and seek passive self-regulation (Mollison and Holmgren 1982) - provides an important complement to development-oriented thinking by pointing us towards a vision of planning that is not just sustainable but positively regenerative (Brawner 2015: 441; Cole 2012; Girardet 2014), and in which active development is complemented by conscious non-action to hold open spaces for important ecological functions. In this article, I will explore permaculture's potential contributions to urban political ecology by reconsidering one specific urban problem - vacant land - through the concept of the fallow.

I propose that developmentalist thinking and a focus on classically urban landscapes has led to widespread misrecognition of the nature of the vacant land problem, and that this problem cannot be resolved except through a reorientation of urban norms and practices to accommodate diverse and multi-functional fallows as a widespread feature of urban and suburban environments. In making that case, this article turns on two permaculturally-minded intentional communities in the Pacific Northwest, whose physical and social structures apply the theoretical approaches advocated in this article. Following parallel introductions to New Urbanism and permaculture, and a brief review of the literature on vacant land in cities and the range of ecological approaches that have been brought to bear on the problem, a study of Portland's Kailash Ecovillage shows its successful convergence of New Urbanist and permacultural thinking in an urban setting, where 
functionally vacant land has been replaced by a thriving urban oasis. However, as we move beyond conventional accounts of vacancy to consider the systemic causes of wasted land in American aesthetic, economic, and legal norms, it becomes apparent that many of the conventional ecological and New Urbanist solutions in the literature are inadequate. They are responding to the symptoms of urban blight while failing to recognize land that is ecologically and socially wasted, dominating our urban and suburban landscapes, and this problem is most acute not in the post-industrial and inner city neighborhoods associated with vacancy, but rather with lowdensity residential areas. I therefore turn to Songaia, a suburban cohousing community outside of Seattle, to examine how a permacultural approach to fallow land can help us to design richer and more functional ecosystems on a wider scale.

\section{New Urbanism and Permaculture}

New Urbanism can largely be understood as a reaction against the worst tendencies of the modernist urban planning that dominated the mid- $20^{\text {th }}$ century with what was "no more, and no less, than an aesthetic ideology - a strong taste for classic lines... a legible grid that could be easily grasped at a glance and could be repeated in every direction... an abstract, linear city" typified by a tidy separation of functions (Scott 2008: 108; see also Gray-O'Connor 2009: 131). Perhaps the greatest antagonist of this approach, and the progenitor of New Urbanism, was Jane Jacobs. Jacobs was not trained as an urban planner, architect, or an academic; instead, she was an activist who helped to lead the resistance to grandiose urban renewal and infrastructure projects in New York City (Scott 2008: 132). While the modernists saw the city from above in maps and models, Jacobs' fundamental insight was to work from street level; rather than creating attractive plans and seeking to impose them upon the city, she looked to real streets and neighborhoods for inspiration. For Jacobs and the various stripes of New Urbanists who followed her, the keys to a successful city were the things that modernist planners had largely thrown away: density, flexibility, mixed uses and incomes, and designs built on a walkable, human scale. As Jacobs wrote, "simple regimented regularity and significant systems of functional order are seldom coincident in this world... A city's very structure consists of mixture of uses, and we get closest to its structural secrets when we deal with the conditions that generate diversity" (Jacobs 1992: 376). Both the lifeless downtown business district and the endless sameness of suburbia stand as testaments to the need for fine-grained diversity in urban structure.

A critique of socially and spiritually stultifying suburbia is at the heart of New Urbanism, which asserts that "sprawl is damaging to human as well as nonhuman nature; neotraditional towns are a more natural alternative" (Till 2001: 223). New Urbanist developments therefore seek to recreate the sociability, walkability, and stimulating diversity of traditional urban neighborhoods, calling for cities to be "compact, walkable, mixeduse, and transit-friendly and to contain a diverse range of housing", with a faith born of its roots in architecture and design that "changes in physical form are a necessary precondition for urban economic, social, and ecological change" (Till 2001: 222-223; see also The Charter of the New Urbanism n.d.). Neotraditional architecture and town planning, therefore, are meant to afford the possibility of new and preferable lifestyles, with beneficial human and environmental effects, and this approach to design has gained considerable influence in recent decades, with the principles of New Urbanism widely invoked - if unevenly applied - by developers, architects, and government (Bohl 2000; Knaap and Talen 2005: 109).

While New Urbanists advocate "sustainable growth" rather than degrowth (Garde 2004), these philosophies share common ground in seeking to show that it is possible to simultaneously limit consumption and improve quality of life through attention to community and common goods. A concept of nature as a good to be preserved - both for its own sake and as an amenity for humans - is therefore central, with New Urbanist developments employing smaller lots and denser construction in order to reserve larger natural spaces than conventional suburbs (J. Kim and Kaplan 2004: 320). However, as Till points out, the concept of nature advocated by New Urbanists tends to reflect the dominant American - and typically white, middle-class, and urban - wilderness ideal, with nature conceived as separate from humans and valued for spiritual and aesthetic rather than practical reasons (Till 2001; see also Cronon 1996; Nash 2001). The New Urbanist approach to ecology is therefore one marked by a conservationist attitude that seeks to limit harm by managing consumption and designating refugia set apart from humans, rather than a restorative approach that aspires to build environments that enhance ecological function within the urban matrix; or, as Cole writes, "[r]egeneration, in 
contrast to this emphasis on 'doing less harm,' carries the positive message of considering the act of building as one that can give back more than it receives... thereby over time building social and natural capital" (Cole 2012: $3)$.

I first encountered Jacobs not in a book of urban theory, but a permaculture manual. This may seem strange: while Jacobs wrote that, "to be frank, I like dense cities best and care about them most" (Jacobs 1992: 16). Permaculture One, the movement's founding document, laid out a theory of agroecological design to an audience of back-to-the-landers (Mollison and Holmgren 1982: 2). However, while permaculture continues to be associated primarily with a system of agriculture, its "ethics, principles, and methods can be applied not just to gardens but to all essential needs" (Hemenway 2015: xi; Pickerill 2013). This is because at its most basic, "[p]ermaculture is applied whole-systems thinking... the idea that we need to look not just at the parts but at the connections and relations between parts, and how the whole is more than just the sum of the parts" (Hemenway 2015: xvi; Pickerill 2013: 186-187). Both design philosophies thus share a strong preference towards diversity, interdependence, and human-scale solutions - albeit with sharply differing styles, New Urbanism in a conventional liberal bourgeoise mode (Pyatok 2000), while permaculture goes beyond sustainable growth to degrowth to seek out utopian possibilities (Lockyer and Veteto 2013).

Permaculture practitioners follow a design philosophy oriented around three ethical fundamentals "earth care, people care, fair share" (Permaculture Ethics n.d.) - and an evolving list of design principles. Although the precise number and formulation of these principles vary, they almost always include:

- Observe and interact: any intervention should follow prolonged experience with a given site.

- Connect: individual elements in a design are subordinate to the whole which they create; a whole is not a collection of parts, but rather the parts must be assembled to serve a functioning whole.

- Stack functions: each element should serve many different purposes.

- Catch and store energy and materials: all waste is an opportunity, and it should be captured and used to meet a need elsewhere in the system.

- Collaborate with succession: recognize that change is natural, and that rather than wasting energy trying to hold a system in stasis, it is far wiser to build in such a way that change is positively advantageous (Hemenway 2015: 24-25).

In sum, these principles call designers to build for flexibility and exuberant diversity as the keys to living systems that are stable, resilient, and self-regulating, and that require minimal inputs (including labor) to maintain. In a mature, well-designed system, conscious non-action should be the norm.

In implementing these design principles, permaculturists employ a number of strategies consistent with the imperative to focus on relationships rather than components. "Functional analysis" reminds permaculture designers that, "[i]n good design... needs and resources are connected to other elements; that is, the product of one activity is arranged so it provides something that another element requires" (Hemenway 2015: 33). It sounds obvious - but it is something that generations of city planners failed to understand when they zoned residents out of business districts, creating downtowns that become abandoned and frightening at night, residential areas without shops or restaurants, and untold traffic and pollution in between. "Zone analysis" is another seemingly obvious concept: "[p]lace the things you use the most or that need the most attention near where you are" (Hemenway 2015: 35). Yet many an attractive city park or plaza has become a trash-strewn wasteland because it was situated in an area without natural foot traffic; many a school garden has sat unused and overgrown in a distant corner of campus. If their creators had used zone analysis in their planning, they might have spent their resources more effectively, situating their projects where they would be appreciated and leaving these distant corners fallow for the birds and butterflies.

While permaculture has largely been developed by non-academic practitioners as a "feral" science (Morris 2012), Lockyer and Veteto assert an intellectual "affinity among... permaculturalists, and ecovillagers and ecological/environmental anthropologists and multidisciplinary political ecologists", and propose that 
scholarly engagement with these "living laboratories of cultural change... represent opportunities to make environmental anthropology more relevant to immediate concerns" (Lockyer and Veteto 2013: 24). These affinities are perhaps most evident in permaculture's call to "garden like the forest" (Jacke and Toensmeier 2005: 4; Mollison and Holmgren 1982: 3) and its invocation of the agroforestry systems that have also been of much interest to anthropologists. One such system, the traditional forest gardens of Chiapas's Lacandon Maya, include up to 79 species, with annuals like beans and corn planted among fast-growing tree crops like papaya and bananas. Following an initial period of intensive cropping, the plot is allowed to grow up into a forest wild in appearance but dominated by useful trees and herbs that need little regular maintenance (Nations 2006: 138139). In Indonesian Borneo, Tsing describes a similar system of semi-wild orchards, writing that

...different forms of planting are recognized, ranging from the deliberate burying of seeds to the more casual sprouting of a rubbish heap. Furthermore, there are many human practices other than planting that are recognized as encouraging specific plants... Fruit tree biodiversity is maintained in part by those human-fruit interactions that fall somewhere in the gap between cultivation and the wild" (Tsing 2011: 178)

In stark contrast to the American human-nature binary critiqued by Till, these agroforestry systems recognize many categories of loosely managed land occupied by complex perennial polycultures, introduced and favored by humans but largely self-regulating. These are fallows not in the conventional western sense of an unproductive but necessary resting state or a break in use, but rather a valued and productive phase of land use in its own right.

Thus, despite arising from very different contexts, and training their sights on different sorts of systems, permaculture and New Urbanism share key preoccupations with functional rather than visual order, humanscale design, and the integration of elements. Jacobs writes that the "ubiquitous principle is the need of cities for a most intricate and close-grained diversity of uses that give each other constant mutual support" (Jacobs 1992: 14); Permaculture One instructs that "[e]ach element serves several functions in the ecosystem, and each functions in common to many elements. Thus as system of checks and balances develops... Design and support systems with maximum flexibility and diversity" (Mollison and Holmgren 1982: 6). New Urbanist James Kunstler argues that "[i]gnoring the relationship between the things and fetishizing buildings, the cult of Modernism promoted all the discontinuities of the common sprawlscape. The relationships created there were horrible because no thought went into them" (Kunstler 1993: 250). Permaculturists argue that "relationships are just as important as the parts - sometimes even more so" (Hemenway 2015: 22), and that "[t]he purpose of a functional and self-regulating design is to place elements or components in such a way that each serves the needs, and accepts the products, of other elements" (Jacke and Toensmeier 2005).

Beyond these shared emphases on diversity and relationships, New Urbanism and permaculture are also marked by a mutual interest in community as a practical organizing principle. The concept of community has a longstanding if often vague usage in the social sciences to refer to a more or less modestly sized group of people, often but not always geographically defined, that shares a sense of common identity and values, and - perhaps most importantly - recognizes itself as a community (Anderson 1994: 6; Brunt 2001; Redfield 1960). In Keywords, Raymond Williams writes that

[c]ommunity can be the warmly persuasive word to describe an existing set of relationships, or a warmly persuasive word to describe an alternative set of relationships. What is most important, perhaps, is that unlike all other terms of social organization (state, nation, society, etc.) it seems never to be used unfavorably, and never seems to be given any positive opposing or distinguishing term. (Williams 1983: 74)

Precisely this common-sense understanding of community - and a conviction that modern globalized society has eroded community - undergirds both permacultural and New Urbanist thought. Casting a nostalgia eye towards traditional neighborhoods as supposed sites of a richer, less atomized sociality than contemporary 
suburban developments, New Urbanists seek to use a variety of design features - pedestrian pathways, front porches, neighborhood shopping districts - to encourage the use of public space and create sites for casual interaction and chance encounter, although scholars have reported mixed success in achieving these social aims (Grant and Perrott 2009; J. Kim and Kaplan 2004; Talen 1999). As with the other criticisms of New Urbanism, the trouble seems to be that the movement is fundamentally rather more modest than its more enthusiastic proponents might suggest (Beauregard 2002; see also Bohl 2000). Front porches and public plazas may help to draw residents outside and create a friendly ambience, but it is unclear that, in the absence of socio-political structures for shared governance of some common good, such design features in themselves can produce the sort of robust community described by Etzioni as a "web of affect-laden relationships among a group of individuals, relationships that often crisscross and reinforce each other... [and a] measure of commitment to a set of shared values, norms, and meanings, and a shared history and identity - in short, to a particular culture" (Etzioni 1996: 127).

Permaculture too is built on a concept of community, although more robustly theorized and intensively practiced than within New Urbanism. While relations among non-humans may not share the affective elements described by Etzioni, the horizontal web of mutually reinforcing relations that he describes as the structure of community is essential to permacultural conceptions of ecology and appropriate design. Permaculture has thrived within the ecovillage movement, and is often practiced alongside or through experiments in communal or cooperative living (Lockyer and Veteto 2013), but even outside of such dedicated residential settings, networks of permaculturalists have formed "distributed ecovillages" within cities:

With every new development of our yard, additional neighbors stopped by to lend a hand, ask some questions, or have a look around... Out of these casual interactions have grown many strong connections within the neighborhood, with functional interrelationships... set in place. The transformation of our yard has not only offered me an intimate partnership with the local ecology, it has woven the social connections back into the living system that is this place. (Haluza-DeLay and Berezan 2013: 141-142)

These sorts of cooperative, horizontal, mutually supportive, and values-driven relationships are central to permaculture.

The two communities discussed in this article, Kailash Ecovillage and Songaia Cohousing Community, describe themselves not only as communities, but intentional communities: "group[s] of people who live together or share common facilities and who regularly associate with each other on the basis of explicit common values" (Fellowship for Intentional Community N.D.). Such communities fall within a long tradition of often utopian experiments in communal or cooperative living that runs through charismatic religious communities, socialist collectives, and hippie communes to contemporary ecovillages and cohousing communities (Kopp 2009). These are communities not only in the looser sense that a nation, religious or ethnic group, or New Urbanist development might be, but are defined by face-to-face relationships, egalitarianism, joint decisionmaking and a significant level of cooperative communalism. In explicit contrast to the social fragmentation and isolation of modern life, intentional communities seek to re-create a form of commons, enacting a critique of the dominant culture (Manzella 2010: 7); "[w]hen people in mass society face difficulties in making the human connections necessary to sustain them - or when the rules and understandings that once served them well no longer apply - they turn away from their existing communities and towards intentional community with an eye towards setting things right in a more intimate setting" (Brown 2002a: 6; see also Brown 2002b). In permacultural terms, these communities "operate as niches... for social, cultural, and lifestyle experimentation" (Henfrey and Ford 2018: 7), whose diversity, it is hoped, will provide a seedbed for livable alternative futures. And while studies of such community tend to focus on their social and cultural organization, their "physical structures are crucial in enabling these more social materialities of communing to be practised... the physical structures, how eco-communities are materially built, shape how the commons work (or not)" (Pickerill 2015: 17). 


\section{Ecological approaches to wasted land}

Vacant land ${ }^{2}$ is generally regarded by neighbors, planners, and scholars alike as a sign of blight - a sickness of the city to be cured through redevelopment. It has been characterized as "one of the most visible and demoralizing signs of inner city decline" (Accordino and Johnson 2000: 301), a blight that "spreads by contagion" (Bowman and Pagano 2004: 2) and is "associated with violence, fear and further disorder" (Garvin, Cannuscio and Branas 2013: 198), attracting trash, homeless camps, drug use, and other unwanted uses. Wasted land is often described almost as generative of the undesirable activities and substances which it accumulates, but not all wasted land is created equal. Of the four broad categories of vacant land, only the final category, the TOADS, is the object of much concern, while the others are seen as essentially benign, and often excluded from discussion altogether.

1) remnants undevelopable due to size, topography, or other features;

2) reserves for future development,

3) buffers held open around other infrastructure, and

4) temporarily obsolete, abandoned, or derelict sites (TOADS), including brownfields and abandoned inner city lots (Németh and Langhorst 2014: 144)

The focus on TOADS leads to a mistaken perception of sites and signs of vacancy as a cause of crime and neighborhood decline, overlooking the role of disinvestment and the flight of capital: "vacant lots are not, at the root, an open space problem: they are primarily an economic problem" (Foo et al. 2013: 180). This is not to argue that vacant lots are not frequently polluted, menacing eyesores, detrimental to neighborhood stability; clearly, many are. However, too often the focus on abandonment as a cause of unwanted behaviors results in misguided solutions in the vein of broken windows policing (see Harcourt 2001), which criminalize the people who frequent these places in the belief that this will somehow transform places into something more desired. Given that suburban vacant land can be described as "Eden in a vacant lot" and "a source of intimacy and education that contemporary culture can scarcely afford to lose" (Pyle 2002: 305), we should question the extent to which blight is a natural feature of unused land rather than an effect wrought on certain parcels of vacant land by poverty and neighborhood disorganization.

Ecological approaches to vacant land have sought to undercut its traditionally negative image by drawing attention to the significant ecological services these landscapes can provide. Open land reduces runoff and flood risk, improves air quality, and limits the urban heat island effect (Fuller et al. 2007; Heynen 2006; G. Kim, Miller, and Nowak 2015; Wolch, Byrne and Newell 2014). Green space reduces stress and improves health (Hillsdon et al. 2006). Vacant land shelters many useful and pleasant species, and serves a potential role in conserving biodiversity at a time when habitat loss is a major driver of extinction (Dana, Vivas and Mota 2002; Vessel and Wong 1987). Worn paths, signs of camping, and empty bottles suggest human uses (Wilk and Schiffer 1979), and despite the tendency to focus on illicit activities in wasted land, "nothing is less empty to a curious, exploring child than a vacant lot", and these spaces can be important sites of childhood discovery in nature (Pyle 2002: 306; see also Mäkinen and Tyrväinen 2008). In all of these important senses, vacant lands are far from empty.

Alongside passive, ecologically-grounded approaches focused on recognizing the abundance of functions already offered by open land, landscape architects have looked to prominent designs like Seattle's Gasworks Park and New York City's High Line for new landscape aesthetics in which post-industrial ruins are incorporated into parkland (Hollander et al. 2009; Southworth 2001). Mainstream American park design descends from the idealized pastoral landscapes of English manor gardens and Olmstead's classic parks, which emphasize naturalistic forms over functioning ecological systems and center on swathes of close-cropped lawn

\footnotetext{
${ }^{2}$ Vacant, abandoned, unused, open or wasted land - it goes by many names, and in the interest of variety, and appreciation of their slight distinctions in tone and implication, I use all these terms freely in this article to refer to urban land that is either managed minimally or not at all and that does not serve a recognized purpose.
} 
(Cranz and Boland 2004, 108; Spirn 1996). This last feature is of course the element which has been most enthusiastically adopted in American vernacular landscaping, and lawns now cover nearly a quarter of our total urban area, leading to the widespread application of toxic chemicals and the expenditure of billions of dollars and countless hours of labor in the ongoing struggle to permanently arrest an ecosystem in an immature monoculture that provides few ecological services (Robbins 2007).

Ecological landscape designers criticize the cultural requirement to disguise ecological and historical processes in our landscape design. Functional landscape design "attempts to express and make visible those [ecological] processes; it is the antithesis to the frozen moment in time" (Baird 2003). In contrast to the lush appearance and toxic sterility of conventional lawns, ecological landscape design seeks to manage runoff, remediate contamination, and create habitat while still providing an attractive appearance; after all, if an urban landscape is not attractive "no amount of sustainability will ensure that it will still be standing in twenty years" (Baird 2003: 10). In order to overcome the strong cultural aversion to unkempt and abandoned land, ecological designs should "incorporate adequate design cues to care" (Nassauer, Wang, and Dayrell 2009: 290) such as mown pathways or edges, "making them perceivable as an intentional landscape" (Cranz and Boland 2004: 109). These landscapes, though still exceptional, are becoming increasingly common and offer a new set of aesthetic perceptions and design practices through which the potential of wasted land can be realized.

Perhaps the most widespread subject of interest among those seeking to reclaim abandoned land is community gardening. While these gardens occur in all types of communities, the literature focuses on those located in the poor, minority neighborhoods where vacant lots are understood as most problematic (Drake and Lawson 2014; Langegger 2013; Levitt 2017; McClintock 2008; Saldivar-Tanaka and Krasny 2004). Community gardens create a variety of well-documented (though poorly quantified) benefits: increased access to healthy food, community organization and pride, a source of income, as well as the range of ecological and aesthetic benefits associated with green spaces more generally (Drake and Lawson 2014; Kennedy 2008; McClintock 2008). However, in many cases - notably New York community gardeners' long battle against Mayor Giuliani's attempts to redevelop their plots - the story comes to be dominated by fights against development interests both in and out of local government (Saldivar-Tanaka and Krasny 2004), as the success of gardens contributes to gentrification and increased land values (Foo et al. 2013: 176). This pattern is due in part to the fact that community gardening, though a long-established feature of American cities, continues to occupy an uncertain position, never having achieved widespread acceptance as a basic public good (Lawson 2009).

In her excellent study of community gardens in Columbus, Ohio, Moore questions why, despite a century-long history, gardens continue to be regarded as temporary responses to economic crisis, rather than ongoing public services on par with parks or playgrounds. She argues that:

the representation of these spaces as crisis landscapes helps to perpetuate, rather than challenge, an urban normative that excludes both productive nature and non-capitalist commodity production and communal relationships... Possibilities for alternative spatial practices and urban spaces were eliminated as neighborhoods were molded to mirror/support the urban normative (Moore 2006: 188).

Moore's insight is part of an urban ecologist tradition who have pointed out that our concept of the city - what she refers to as the "urban normative" - has been constructed in explicit contrast to the rural and the natural (Williams 1973), and that therefore natural processes within cities are either rendered invisible (Gandy 2003; Kelman 2003) or, in the case of community gardens and vacant lots, regarded as temporary aberrations from the natural urban order of construction and commerce. Even the name by which we call these landscapes vacant - "renders such spaces invisible and characterizes them by the lack of traditional or conventional urban activities that happen on the lots" (Pearsall and Lucas 2014: 121). They become absences, spaces waiting to be filled, rather than places in their own right. This invisibility of vacant lots is not inherent feature of their appearance: parks are not regarded as vacant; neither are sports fields, nor - outside the city - forests and plains. 
Rather, vacancy is a relative status, and because the urban normative defines all non-development uses as foreign to the nature of the city, these places are classed as vacant and their meaning defined by past and (presumptive) future use, obscuring all positive value associated with their current state.

\section{Living permaculture in the city: Kailash Ecovillage}

Permaculture's first principle is to "Observe and Interact." It must be learned not only through theory but also direct experience and tinkering. I am at best an amateur permaculturist, but I gained what knowledge I do have through my experiences prior to graduate study, when I lived as a member of two permaculture-inspired intentional communities in the Pacific Northwest: Songaia Cohousing Community, where I was a residential permaculture intern for the summer of 2013, and Kailash Ecovillage, where I lived as a member from August 2013 through July 2014. Both communities can speak significantly to the problem of vacant land in American cities, and illustrate the ways in which permaculture can help us convert this problem into a resource. Unlike more radical communities where environmental commitments can produce a sharp separation from mainstream society (e.g. Lockyer 2017), Songaians and Ecovillagers lead lives that would be familiar to most Americans but they lead these lives in physical settings designed with permaculture principles in mind. In the context of this article, the relative moderation of both communities represents an advantage, since it is not so great a leap to imagine that their examples could be both broadly appealing and implementable in a range of conventional urban and suburban settings.

Kailash Ecovillage occupies about 0.4 hectares in southeast Portland, Oregon, and consists of a low-rise apartment complex and the adjacent house (Figure 1 and 2). The community explicitly describes its design and mission in terms of permaculture, and members have been actively involved in local permaculture networks. Prior to the community's founding, the building was reportedly known as the "meth apartments", with a high vacancy rate and reputation for crime; the grounds were divided between a paved parking lot and a wide, barren lawn at times overgrown with brambles. Unusually for an ecovillage, the entire complex is owned by a couple that founded the community, established its initial norms and principles, and who still live on site and act as leaders in the community. However, while they retain a clear degree of power within the community - most obviously the fact that they collect rent - day to day decisions are generally discussed among residents. Never in my year living there did I witness or hear described an instance in which these unconventional landlords acted unilaterally or contrary to general opinion in imposing a decision on the community; however some residents did suggest that this less than democratic structure may have inhibited some from engaging fully in the community.

Today, a decade after its reinvention as Kailash, it has a population of about 60 people, primarily in affordable one-bedroom rental units (Kailash Ecovillage 2017). Because of its urban location, many Ecovillagers rely on non-car transportation to meet most of their needs, and the community's parking lot has been subject to several rounds of de-paving to open up more garden space and limit runoff (Depave 2017). In keeping with the permaculture principle of catching and storing energy and materials, rainwater is captured and conserved in cisterns and swales, and community composting of food scraps, composting toilets, and the use of woodchips - a waste product dumped by local arborists - all contribute to soil fertility. Further efforts towards efficiency include the installation of solar panels and the retrofitting of a small house on the property to meet passivehaus standards, meaning that it is designed and built to require only the barest minimum of heating.

At present, nearly all of the property is maintained in a productive and attractive organic garden, with large swaths of vegetables tended by a co-op of residents, and smaller patches available to those who want to keep a personal garden. Surplus is shared on a "free table," and it is a rare day during the growing season that residents cannot help themselves to produce. Following the permaculture zone system, areas that are most visible and intensively used are reserved for ornamentals, herbs, and plants requiring active tending, while the far corners are used for low-maintenance perennials. Directly outside the buildings are berries and flowering plants that provide forage for several resident beehives; outer areas hold over 50 fruit trees; and cane berries, grapevines, and kiwis are trellised on the fences surrounding the property (Gardens 2017). Small decorative elements - knee-high buddhas, windchimes, rain chains - and flowers are interspersed throughout, and weeds 
are diligently suppressed to a degree not typically practiced by permaculturalists in order to ensure that the lush gardens remain acceptably tidy and attractive for their urban setting.

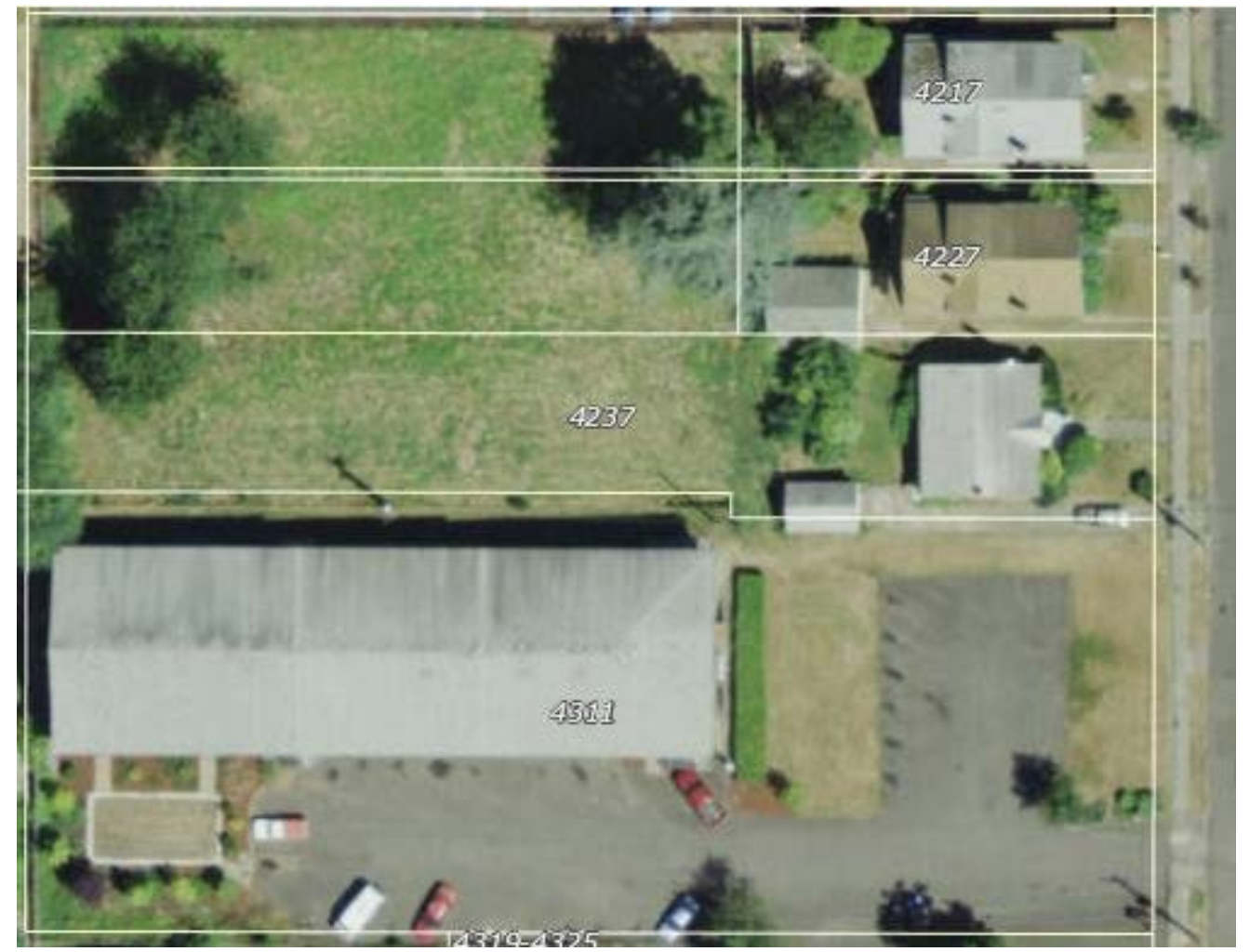

Figure 1: The Kailash site in 2007, before the beginning of the ecovillage. Like most apartment complexes in the area, it has a large parking lot and an expansive lawn. (Kailash Ecovillage 2017)

While gardening is central to the community's identity, Kailash is not merely an intensively cultivated urban farm. While the Ecovillage has done away with its lawn, the garden contains numerous distinct social niches: a patio and picnic area directly beside the main entrance; a fire pit; children's play area; a shared bike and tool shed; and, in the most distant corner, a quiet grove for meditation. In short, in contrast to the neighborhood's many comparable apartment complexes, which ring themselves in monotonous and little-used lawns, Kailash makes deliberate use of virtually the entire property by densely layering many diverse ecological and social uses. This design has successfully converted the garden into the social center of the community - not only for work parties and harvests, but also potlucks and bonfires, afternoons reading in the shade of a fig tree, or neighbors stopping to admire a roosting owl in the big spruce tree. In sum, while the garden serves obvious productive functions in growing food for residents and creating an ecologically diverse and functional habitat, this dense, inviting environment also creates the opportunity for chance encounters very much equivalent to those promoted by Jacobs' call for densely mixed residential/commercial neighborhoods. Thus, not only has an ecologically wasted space been converted to verdant beauty, but a social dead space to be ignored or hurriedly crossed on the way to one's car has been turned into a well-used meeting ground. 
Kailash is a community that has transformed itself into a community garden - an apparently effortless convergence of New Urbanist and permaculture ideals: a dense, highly livable, ecologically diverse oasis in the midst of the city. However, while Kailash is a self-consciously permacultural project, its high population and the eagerness of its residents to engage in the garden means that much of the property can be actively tended and planted with annuals, and no part of the property is left untouched in a long-term fallow. One might therefore reasonably object: this is all very well in Portland, a relatively dense city teeming with aspiring gardeners, but what about the majority of Americans who live in the suburbs and other less-dense residential settings? ${ }^{3}$ More generally, we might doubt whether the high human energy inputs required to create a garden - so suitable for an apartment complex - can be reasonably asked or expected for other sorts of vacant land: for highway margins or toxic brownfields. Songaia Cohousing Community, my second case study of applied permaculture design, will offer a way forward by looking to the design solutions of a suburban permaculture community; however, before turning to that case, it will be necessary to consider in greater depth the structural factors that give rise to unused land, and the reasons why simply filling vacant lots with community gardens will never adequately address the wasted land problem.

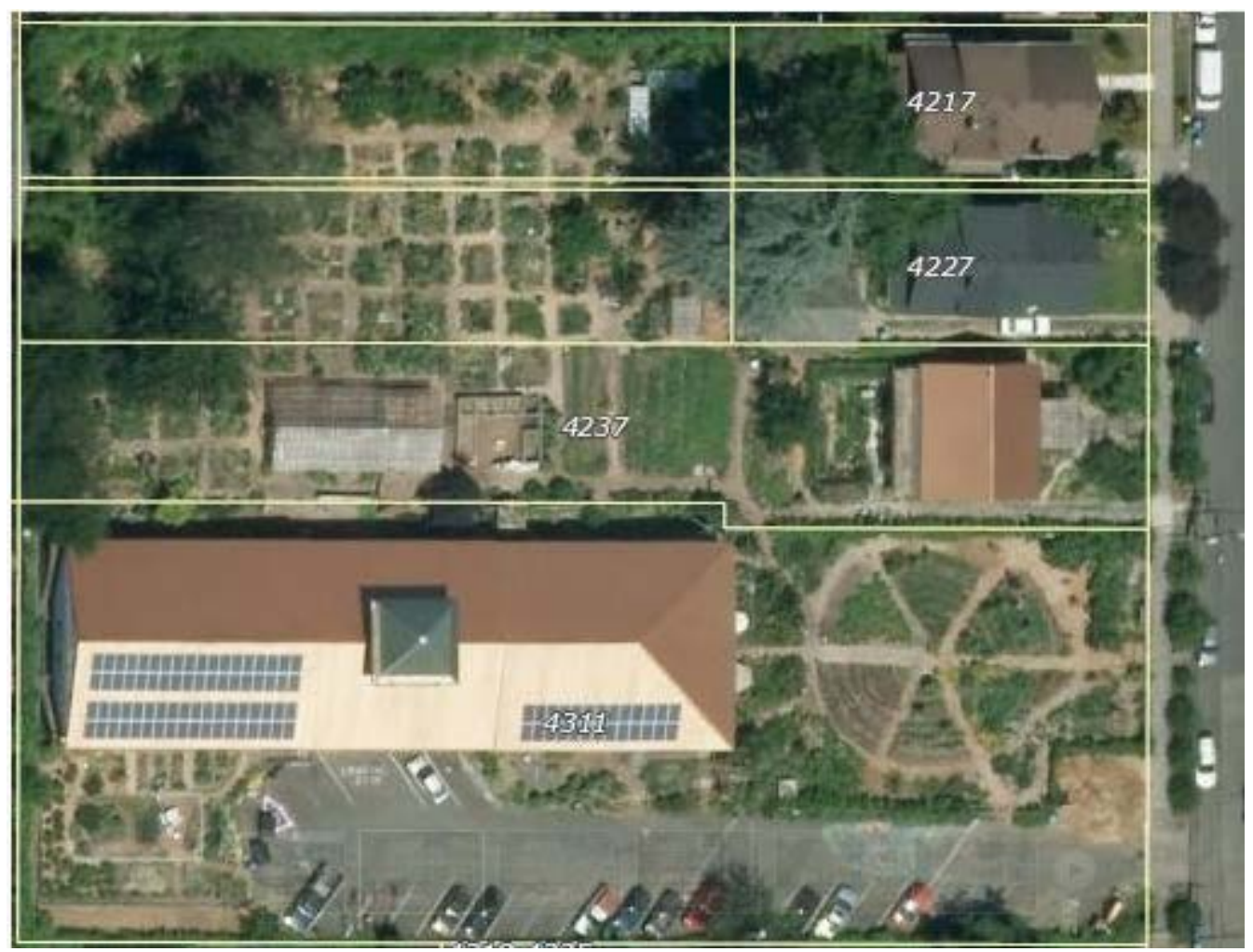

Figure 2. Kailash in 2017. Note the shrinking parking lot, the increased number of trees around the periphery of the property, the proliferation of garden beds, and the appearance of solar panels on the roof of the main building. (Kailash Ecovillage 2017)

\footnotetext{
${ }^{3}$ The US Census does not offer a formal definition of suburbs, and estimates of their prevalence vary according to criteria used. However, in one national survey, 53\% of Americans described their homes as suburban. This description was found to correlate more to zip code density than formal municipality, with majorities of residents in three of the ten largest US cities characterizing their residences as suburban (Kolko 2015). I will follow this convention throughout the article, using "suburban" in its ordinary sense as a low-density residential zone regardless of municipal jurisdiction.
} 


\section{The production of vacant land: vacancy as a system}

While Kailash is an admirable application of permaculture to its urban environment, we must understand the limitations of the lessons that we may draw from it. Returning to Moore's concept of the urban normative, which values development, active use, and permanence as basic qualities of appropriate land use, it is clear that while the Ecovillage challenges much about our conventional approach to building cities, it ultimately fits neatly within or beside these norms. Functionally vacant space existed, and it was filled. However, if we are to progress beyond conventional prescriptions for vacant land, we must do more than simply recognize different sorts of vacant land and plant them with gardens. Instead, a more comprehensive analysis of the systems that produce and reproduce vacancy will be necessary before continuing to my second case study.

Alongside the developmentalist urban normative's emphasis on growth as the nature of a healthy city, a concept of permanence is equally essential to understanding why vacant lots' informal and semi-formal uses are devalued. Currently, "informal uses of vacant lots that emerge outside the traditional planning framework are treated as temporary solutions to the vacant lot problem until a development proposal emerges" (Pearsall and Lucas 2014: 121). While the ecosystem services of an overgrown lot and the productive and neighborhoodbuilding capacities of community gardens provide important and measurable benefits, as uses dependent on the continuing non-development of open land they are regarded as inherently temporary. US property and urban planning systems emphasize long-term use by private owners; while various programs in a number of cities make temporary use of abandoned land possible, they are often ad hoc, precarious, and each new project requires considerable organizational energy and careful negotiation to achieve precisely because they fall outside recognized categories of normative urban land use (Bishop and Williams 2012).

Given that immediate development is neither possible nor desirable for all open sites, Németh and Langhorst argue that a more robust system to allow for temporary use would provide the best way for communities to access the potential benefits of wasted land (Németh and Langhorst 2014: 145). They go beyond a simple practical claim to argue that a new urban normative capable of encompassing a variety of temporary uses as a legitimate part of city life has the capacity to "expose the ongoing conflicts and contestations between competing value systems, interests, agendas and stakeholders... Rendering visible the hidden mechanisms and machinations in the production of urban space can be instrumental in managing competing agendas and interests in a more just and equitable manner, addressing conditions of uneven and unjust development" (Németh and Langhorst 2014: 147). In fact, temporary projects on vacant land like Los Angeles' South Central Farm and Portland's Right 2 Dream Too tent city have become focal points in community resistance to development (Kennedy 2008; Przybylinski 2015), since these temporary uses created bonds among local residents, and between them and otherwise invisible and neglected lands, leading to greater concern with and involvement in debates over appropriate and desired usage and redevelopment.

While vacancy is a temporary state for most specific parcels of land, vacant land as a category of land use appears to be a permanent feature of the modern city. The percentage of land standing vacant remains relatively consistent across cities (with regional variations), and such land exists in both growing and shrinking cities - even allowing for relatively narrow definitions of vacancy that exclude many of the forms of wastage considered in this article. While temporary land use regimes would represent an important step towards a more productive and beneficial place for abandoned lots within cities, a full understanding of these landscapes therefore also requires examination of the features that lead to their consistent and ubiquitous production.

In cities with the most dramatic and visible vacant land problems - places like Detroit and St. Louis widespread vacancy and abandonment, especially in industrial and inner city areas, can be directly traced to cycles of investment and disinvestment (McClintock 2008; Southworth 2001). Both industry and housing development over at least the past century have followed a more general pattern of capitalist

...landscape modification in which only one stand-alone asset matters, [and] everything else becomes weeds or waste. Here, attending to living-space entanglements [i.e. community and ecological connections] seems inefficient, perhaps archaic. When its singular asset can no longer be produced [or loses value], a place can be abandoned... Thus, simplification for alienation produces ruins, spaces of abandonment." (Tsing 2015: 5-6) 
The ever-increasing mobility of capital and the ability for multinational corporations to shift production around the world in search of higher profits, combined with simplified land use regimes, virtually guarantees the continued creation of new wasted lands, even as others experience redevelopment.

While the dramatic rise and fall of neighborhoods and industries is an important engine for the continual creation of TOADS, other forms of vacant land are generally produced by more mundane, insidious mechanisms. Pre-Industrial cities grew "without specific plans for development, [so] the tightly built urban environment allowed adjustment and adaptation of buildings, open spaces, and streets as desired" (Garde 1999: 201). In the absence of generalized building regulations, space was utilized in a site-specific manner, and where open land was preserved within built-up areas it was generally to serve some purpose. In a dense modern city center, high real estate values can create a similar effect. However, in most American cities and suburbs, open space is not generally a result of a positive decision to leave room for some use, but rather is an expression of a pastoral aesthetic norm that prizes spacious lawns and the zoning restrictions and neighborhood covenants that give these norms the force of law. In a revealing map (Figure 3) contrasting block layouts in Jaisalmer, an unplanned, historic city in India, with Los Angeles, built under a modern American planning regime, Garde makes clear the way in which the application of universal rules regarding set-backs from roads and property lines systematically creates unused and purposeless space as an integral part of the built landscape, well beyond the classic image of the vacant lot.

The result is a landscape - the genealogy of which can be traced through historical phases of urban rationalization, top-down planning, and Progressive Era public health concerns for air flow and sunlight - that is "produced in segments... [and] when combined they generate distinct patterns of a singular open space between buildings and the street" (Garde 1999: 201-204). Because these spaces are created in accordance with a general pattern, rather than responding to any local need or desire, many if not most are underutilized, unproductive, and generally maintained as ecologically disastrous lawns by unenthusiastic owners (see Robbins 2007). In this broadest understanding of wasted land, the concept is opened to reveal how our system of urban design gives rise to a ubiquitous pattern of land that, while not usually conceived as vacant, is in fact largely without ecological or social value.
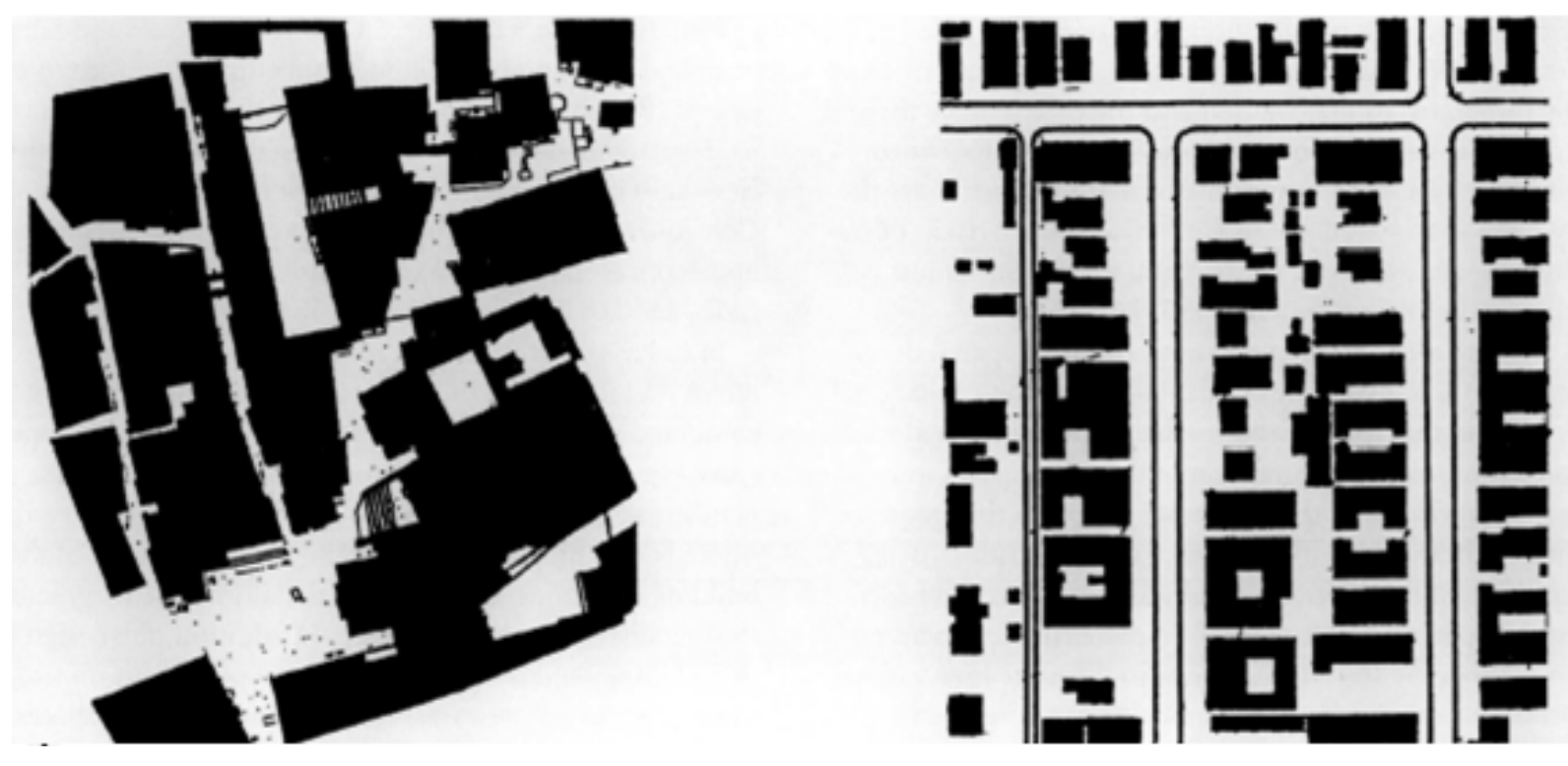

Figure 3. Jaisalmer, India, left, and Los Angeles, CA, right. (Garde 1999: 202) 
If this variety of vacant land has been largely neglected in the literature, and disassociated from the TOADS that occupy center stage, one reason is the sort of city treated as normative. Jacobs, a Manhattanite and a partisan of her city, consistently advocated for density, wanting even parklands to be bustling (Jacobs 1992: 99). The classical city center is the ideal for New Urbanist design (The Charter of the New Urbanism n.d.; Kushner 2002), and New Urbanists' revaluation of that ideal is closely connected to the revitalization - and gentrification - of once declining city centers (Bohl 2000; Gillham 2002, 187; Gray-O'Connor 2009). While there have been notable New Urbanist developments in the form of neotraditional villages, these projects' reduction of vacant land, broadly understood, is achieved almost exclusively through increased density (J. Kim and Kaplan 2004; Till 2001). Specific plots of vacant land shrink or are filled in, but vacant land as a category remains qualitatively unchanged. Thus, whether from a perspective centered in a neotraditional New Urbanist village or Manhattan, abandoned land looks like a hole in the city: a gap or absence that needs to be filled, and the solution is clear: an urban garden or other temporary use; a park; a new apartment building - in short, the sorts of responses that have been discussed in this article to this point, and that typify recent moves to revalue and revive vacant land. It is this sort of wasted land to which a community like Kailash Ecovillage most effectively responds.

However, despite the progress these approaches represent over a simplistic view of vacancy as blight, they are ill-equipped to confront the systematic production of vacant land by countless minor zoning and building decisions that characterize the less-dense cities and suburbs where most Americans live. The icon of this sprawl is southern California, which inspired members of the L.A. School of urban theory to theorize a "postmodern urbanism" in which "the evacuated core no longer dominates its region; instead the hinterlands organize what is left of the center" (Dear and Dahmann 2011: 68) in a crazy patchwork of suburbs and edge cities. Even New York and Chicago, the old paradigms of urbanism, are surrounded by endless expanses of suburbia; Manhattan is the aberration, not the norm. The L.A. School points out that urban growth in the US is fastest in the Sun Belt, and "across the nation, the fastest-growing urban areas are those 'micropolitan districts' outside of established cities" (Dear and Dahmann 2011: 74). Although suburbs and sprawl have been the object of widespread and justified criticism for their social and ecological problems (Kunstler 1993; Rome 2001; Squires 2002), the fact remains that most Americans call the suburbs home.

Given these realities, a realistic short- or mid-term vision of US cities includes a significant proportion of low-density housing, and so approaches to vacancy must center these landscapes if they are to be meaningfully generalizable. Although it is possible and desirable to steer cities towards increasing density, we must recognize that this is not immediately achievable, and is unlikely to ever be a universal outcome. In short, any comprehensive approach to wasted land must be able to account for developments of varying densities in terms appropriate to their unique open space challenges. While Kailash points the way towards a gentler and more attractive urbanism, its solution of simply filling in the empty spaces with gardens will not be replicable across the sprawlscape that most North Americans call home. Permaculture, which originated in rural settings and is most familiarly applied in the garden, and which brings the habit of zone analysis to appropriately utilize areas of low and high use, offers the possibility for finding ecological value in low-density urban settings.

\section{Living permaculture in the suburbs: Songaia Cohousing Community}

Founded in the Snohomish County countryside but increasingly overtaken by Seattle's affluent outer ring suburbs, Songaia Cohousing Community is home to about 45 people on approximately 5 hectares. Despite the growing developments around it, however, and in sharp contrast with Kailash's density, the community could be mistaken for a New Urbanist nightmare. Certainly the suburban setting, sprawling grounds, lack of accessible transit, and absence of commercial space seem to run directly counter to Jacobs' vision of appropriate design. However, in contrast to the atomization - and resultant car-dependence - of the surrounding suburbs, Songaians are not isolated within their own homes, but instead are in constant collaborative contact with their neighbors, with five shared meals a week cooked in the common kitchen, holiday celebrations, sing-alongs, picnics, work days, and meetings. The community is built on a belief in the importance of dwelling together and sharing resources in order to enrich life, and governed through consensus-seeking collaboration (F. Lanphear 2001). Children have the run of the property, and elders receive care and support that lets them age 
in place without giving up their roles as leaders within the community. In contrast to Kailash, the original Songaians were "accidental permaculturalists" (Pickerill 2013: 192), practicing many of its principles under a variety of other names, and only later formally introduced to permaculture through members of the garden team, several of whom have become enthusiastically involved in local permaculture networks.

Although initially organized as a cooperative, the early members discovered as they worked towards the construction of the site that it would be financially advantageous to adopt the legal structure of a condominium association, ${ }^{4}$ with homes individually owned by members (F. Lanphear 2014: 30), The majority of Songaians therefore own their own units, although there have at times been limited opportunities for rentals. While this ownership structure creates a barrier to those who would join the community, prices at Songaia remain relatively affordable when compared to nearby developments. Members are free to sell their own houses, and new members pass through a process of visits and interviews to ensure that they understand - and are enthusiastic about - the community they will be joining; to date, such transitions have been handled smoothly, aided by the fact that there is generally a list of prospective members eagerly awaiting an opening.

Songaians explain the name of their community as meaning "song of the Earth", and on Monday nights, members gather to sing together before dinner. A favorite songs goes, "I love Songaia, I love community / I love the flowers, the dandelions, and the trees / I love the people, they mean so very much to me" (N. Lanphear 2003). These lyrics capture Songaians' broad community, which includes the land and nonhuman beings who share it, and the importance of this expansive understanding of community is made apparent in the community's physical design. The communal garden is operated according to permaculture principles, generating 1.36 metric tons of organic fruit and vegetables for the community annually (From Garden to Table n.d.); this, along with bulk ordering of groceries and a shared workshop help to save money and reduce waste (N. Lanphear 2002), and to replace community interaction for errands that would otherwise involve a car trip. While many residents commute to Seattle for work (fewer than might be expected, as the community's population includes children and teens who attend school locally, many adults work from home or nearby, and approximately a third of all residents are retirees), car-sharing and carpooling are not uncommon. The rejection of a typical North American car-centric lifestyle is reflected in the community's layout, which places a shared parking lot at the margin, away from the pedestrian-only residential areas.

Songaia's strong sense of community owes much to the vision of its founding generation's deliberate design process, which replicates many of the New Urbanist and permacultural prescriptions discussed above (F. Lanphear 2014, 2001). Despite the expansive property, and in distinct contrast to the standard gridded equidistance of suburbia, Songaians' homes are clustered in a circle around a shared lawn. The residents live in modest duplexes considerably smaller than the McMansions typifying the surrounding suburbs, and these homes are designed to be sub-divisible into smaller efficiency apartments as families change and children move out. Next to the Common House - which accommodates a shared kitchen and dining room, as well as guestrooms, laundry, and other shared facilities - are 1.2 hectares of gardens, an unmown meadow, and an expanding food forest of low-maintenance perennial edibles. On the hillside above, 1.5 hectares have been left in native coniferous forest (Land n.d.): a place for children to play, adults to find quiet, and nature to look after itself. While county regulations require all subdivisions in the area to build swales or catchment ponds to capture runoff, and those of neighboring, heavily paved developments often fill, Songaia's forests and meadows absorb rainwater so well that their catchment basin remains dry enough to serve as a goat pasture, even during Washington's famously wet winters.

\footnotetext{
${ }^{4}$ The community also includes several adjacent properties, which are owned by their residents. These members are not members of the condo association, but are fully socially integrated into the community, participating in the dining cooperative and other communal ventures.
} 


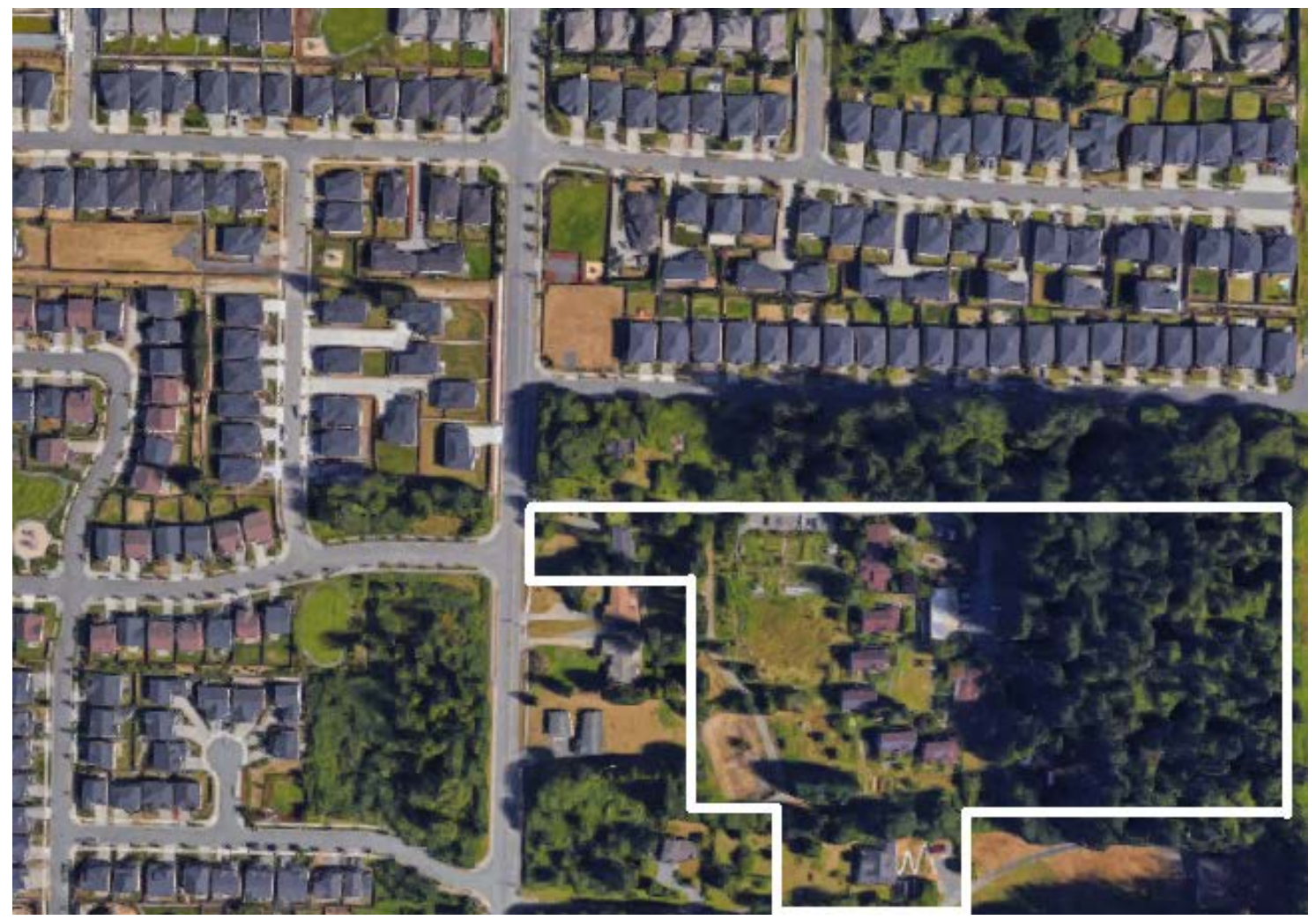

Figure 4. Songaia (with approximate boundaries outlined) and its suburban neighbors. Note the clustering of houses in the center of the property around a small lawn, and the large forest area. Although not obvious in this image, the cleared area to the left of the houses is occupied by gardens, meadow, an emerging 'food forest.' Note also the lack of paved roads within the community, in contrast to the centrality of roads in neighboring developments. The newest round of developments, directly on the community's northern border (discussed below), are not reflected in this image. ("Google Maps" 2017)

By designing their landscape with attention to the intensity of usage, Songaians have concentrated their collective effort on well-kept and well-trafficked inner areas while leaving productive and beneficial fallows across much of the property. This coordination of effort - sharply divergent from the modular layout and repetitious pattern of land wastage in standard American suburbs - allows for a notable diversity that is both aesthetically gratifying and functional. Intensively maintained landscapes - like lawns and vegetable gardens exist there not as a default, but are deliberately placed in focal points where they serve the social needs of the community. By concentrating these uses in the places where are most useful, and by opting for relatively small homes that are clustered together rather than spaced equidistantly, Songaians can enjoy a lawn while leaving larger blocks of space for other, more ecologically productive landscapes that would be unlikely in a less communally-planned development.

For the past ten years, since the wooded adjoining properties were rezoned for development, Songaians have been aware that the rural character of their setting would soon experience change. This was concerning not only because of the noise of construction and the visual disruption to their idyll, but also because one area slated for development included a wetland and several beautiful, mature cedars whose potential removal was a point of particular anguish for some residents. Furthermore, they were deeply concerned by plans for development directly across the driveway from the Common House that called for the new homes to face away 
from Songaia, and a tall fence or wall to run along the property line. For a community rooted in the values of neighborliness and mutualism, the prospect of facing such a stark physical barrier was profoundly upsetting; while most Songaians would have preferred to keep the woods as their only neighbors, given that development appeared inevitable, they were determined to press for a more deliberate and sustainable development process, and to seek ways to open themselves and their community to their new neighbors - to seek points of connection rather than separation (Bonin 2016).

Unable to buy the property themselves - at one neighboring development, the 54 homes under construction were being sold for over US\$700,000 each (Parkview Ridge 2017) - Songaians tried to moderate the development's impacts, first through negotiation with the developers and then through appeals to the county government (Haglund 2016a,b). Although unable to prevent the construction, they won important concessions: the mature cedars slated to be removed and replaced with saplings were preserved, and instead of conventional landscaping along the driveway, the developers agreed to install a food forest - in the process creating a precedent-setting change to county development ordinances (Haglund 2017). Plans for the boundary fence have been modified to allow for pathways and access between Songaia and the new development, and two of the adjoining houses have been purchased by members of Songaia's extended community ("Songburbia"). Songaians have always offered tours and sought to use their community as a model for others; now, they hope their garden and the new food forest can serve as meeting places where they can invite new neighbors into community and perhaps inspire by example (Haglund 2017; compare to Haluza-DeLay and Berezan 2013).

Songaia, like Kailash, uses permaculture design practices to create a landscape carefully tailored to the needs of both its human residents and local ecosystems. Wherever possible, community interactions and harvesting the produce of the land replace driving off-site to purchase goods and services. Rather than an undifferentiated and unused grid of lawns buffering each home, the Songaians have pooled their land resources, deliberately creating shared high-maintenance zones of active use that support and encourage interaction. Since these needs occupy only a small part of their land, in place of the redundancy and waste of a street's-worth of empty lawns, and instead of setting aside the surplus as a purely natural space for purely aesthetic enjoyment, their joint planning allows the remainder of the property to be given over to a variety of fallow uses, arranged in concentric zones of declining intensity and need for maintenance as one moves away from the central living areas, both providing unique habitats and aesthetic and recreational pleasures not usually found in a suburban residential area, and serving significant productive functions that are well integrated into the community's life and consumption habits. Finally, Songaians' efforts around the new development sought to turn a threatening external presence into an opportunity to positively influence their surroundings, and draw new people and resources into their ongoing project.

\section{Conclusions}

Cole argues that a "key distinction exists between green design and regenerative design with respect to place... Being largely technocratic and conceived as a generic, top-down approach, they [green designs] typically lack the specificity and social-ecological engagement central to a regenerative approach... Regenerative design and development, by contrast, seeks understanding of whole systems" (Cole 2012: 3). This local specificity and holism is central to the permacultural approach advocated in this article and demonstrated by Kailash and Songaia. As discussed above, zone analysis is one of the most basic principles of permaculture design: high maintenance elements belong in areas that are naturally trafficked, and low-maintenance elements belong in areas that are not. Guided by a theoretical bias towards city centers, scholars have tended to heavily promote development-oriented solutions suitable for high-use zones while ignoring the larger category of unused land in low-density suburban environments. However, by bringing suburban fencelines and highway buffers together with more traditional vacant lots, we are encouraged to think more holistically - more permaculturally - about wasted land and our response to it. Where there are many people and little space, there are sure to be artists seeking a place to install a temporary work, or gardeners eager to get their hands in the soil. In the suburbs - which represent a far greater population, spatial extent, and environmental impact than dense city centers - a different set of solutions are required. Low population densities, a relative abundance available land, and a greater proportion of land sitting idle mean that individual, labor-intensive projects can 
represent only one small piece of a strategy to give value to vacancy. These are the zones that should be given over to an intentional fallow.

Many of the ecological approaches explored in this article affirm the appropriateness and utility of open land within the city and seek management practices that support ecological vitality. However, whereas boosters of community gardens advocate for the reproduction of a particular sort of landscape in vacant land - i.e., a closely managed garden of edible annual crops - a permacultural approach suggests far more variable uses based on ecological and social factors. Where population density is high and open land is at a premium, a conventional garden may be suitable; where land is relatively abundant and ready labor is more difficult to come by, a lightly managed orchard of fruit trees or berries could be more appropriate. Noisy highway margins, the sprawling lawns of far-flung corporate office parks, and contaminated industrial lands might be suited to native plants and habitat, fungal remediation, shade trees, and flood-abating wetlands. Some areas may be best abandoned altogether, and protected and valued as evolving open spaces for nature, unplanned and sporadic human uses, and the full range of passive environmental services naturally provided by green space (Foster 2014).

A permacultural urban fallows approach is not limited to planting suggestions for more ecologically sophisticated landscaping, however. Like theories describing the production of vacant land as an inherent part of our urban planning and economic structure, a permacultural analysis reveals wasted land not as a symptom of local troubles or urban failing, but rather an indication of flawed (or nonexistent) planning that systematically creates unsightly, unproductive, and ecologically impoverished political ecologies of disuse. While individual projects like those promoted by New Urbanism can turn wasted land to better use, they too often accept and perpetuate conventional notions of vacancy as requiring redemption through active use and intervention. Given both practical limitations and the systematic ongoing reproduction of vacant land, such resource-intensive solutions are unlikely to ever satisfactorily resolve the problem of wasted land. In contrast, a permacultural approach demonstrates that periods of relative neglect are not only normal, but - if planned for and afforded a recognized social place - may be remade into potentially valuable fallows that can provide important ecological services at a variety of locally-appropriate scales and intensities (e.g. Haluza-DeLay and Berezan 2013; Randall 2013). Given greater attention by urban ecologists, permaculture and traditional fallowing practices can provide both theoretical and practical bases for efforts to appropriately manage unused land and to recognize their potential benefits in a new urban normative.

It is tempting to seek a grand solution that, if only scaled up to the size of the world, would resolve all our problems of sustainability and livability and justice. But, as Tsing cautions, "[s]calability spreads — and yet it is constantly abandoned, leaving ruins. We need a nonscalability theory that pays attention to the mounting pile of ruins that scalability leaves behind" (Tsing 2012: 506). Permaculture, which eschews all designs lacking context and ecological entanglement, is one form of nonscalablity theory; while neither Kailash nor Songaia represents a panacea, both communities offer practical suggestions for sustainable and connected living, and demonstrate the applicability of permacultural thinking in a range of settings. And perhaps their most basic lesson is that much of the petty infrastructure of suburban life - everything from lawns to laundry machines is wildly underutilized. If these resources are shared deliberately among an engaged community of neighbors, it is possible to reduce consumption, increase social connection, and replace wasteful vacancy with productive commons, both active and fallow - and to encourage a great deal of beauty and positive social connection in the process.

When held up in contrast to standard development norms, both permaculture communities' carefully planned landscapes make plain the degree to which disuse and wastefulness typify standard urban and suburban land use. While Songaia especially contains many corners that are little-visited, these places are not vacant they do not sit idle and unloved, serving no useful purpose; instead, they have been deliberately fostered, and encouraged in their natural development to create a beautiful and productive ecosystem that is prized by the residents. This is because vacant land is not, as has been commonly supposed, a gap in the city. Instead, a permacultural analysis shows that it is an integral feature, created by a system of planning in which individual homes and businesses are treated as modular units. Each is buffered by its own lawn designed not to serve any social function, nor to maximize ecosystem services, nor as habitat, but simply to frame and separate. Permaculture calls us to think instead in terms of integrated systems, and to deal with each element of the 
landscape as a potentially valuable resource that should support and be supported by the rest of the system. Where neighborhood connections exist, shared landscapes can be created to encourage interaction, and it becomes possible to identify appropriate sites for various forms of healthy fallow, including food forests, wetlands, and woods - to not to fill up vacant land, but also to allow and appreciate its development as fallows that not only preserve but also restore a diverse, bountiful urban ecology.

\section{References}

Accordino, J. and G.T. Johnson. 2000. Addressing the vacant and abandoned properties problem. Journal of Urban Affairs 22(3): 301-315.

Anderson, B. 1994. Imagined communities: reflections on the origin and spread of nationalism. Revised. New York: Verso.

Asafu-Adjaye, J., L. Blomqvist, S. Brand, B. Brook, R. Defries, E. Ellis, C. Foreman, D. Keith, M. Lewis, M. Lynas, T. Nordhaus, R. Pielke, Jr., R.Pritzker, J. Roy, M. Sagoff, M. Schellenberger, R. Stone and P. Teague. 2015. An ecomodernist manifesto. Ecomodernism.org.

Baird, C.T. 2003. Sacred ground: must sustainable landscapes mimic the form and spatial organization of nature? In E. Deming, M. (ed.) CELA 2002: Groundwork. Selected conference papers, Annual Meeting of the Council of Educators in Landscape Architecture, September 25-28, 2002. Syracuse: Council of Educators in Landscape Architecture.

Beauregard, R.A. 2002. New urbanism: ambiguous certainties. Journal of Architectural and Planning Research 19(3): 181-194.

Bishop, P. and L. Williams. 2012. The temporary city. New York: Routledge.

Bohl, C.C. 2000. New urbanism and the city: potential applications and implications for distressed inner-city neighborhoods. Housing Policy Debate 11(4): 761-801.

Bonin, S. 2016. Lessons in participatory democracy. Communities 173 (Winter): 40-41.

Bowman, A.O. and M.O. Pagano. 2004. Terra incognita: vacant land and urban strategies. Washington, D.C.: Georgetown University Press.

Brawner, A.J. 2015. Permaculture in the margins: realizing central European regeneration. Journal of Political Ecology 22: 357-465.

Brown, S.L. 2002a. Community as cultural critique. In Love Brown, S. (ed.) Intentional community: an anthropological perspective. Albany, NY: State University of New York Press. Pp153-180.

Brown, S.L. 2002b. Introduction. In Love Brown, S. (ed.) Intentional community: an anthropological perspective. Albany, NY: State University of New York Press. Pp. 1-16.

Brunt, L. 2001. Into the community. In Atkinson, P., A. Coffey, S. Delamont, J. Lofland and L. Lofland (eds.) Handbook of ethnography. Thousand Oaks, CA: SAGE. Pp. 80-91.

Cole, R.J. 2012. Regenerative design and development: current theory and practice. Building Research \& Information 40(1): 1-6.

Cranz, G. and M. Boland. 2004. Defining the sustainable park: a fifth model for urban parks. Landscape Journal 23(2): 102-120.

Cronon, W. 1991. Nature's metropolis: Chicago and the great west. New York: W.W. Norton.

Cronon, W. 1996. The trouble with wilderness: or, getting back to the wrong nature. Environmental History 1(1): 7-28.

Dana, E.D., S. Vivas and J.F. Mota. 2002. Urban vegetation of Almeria City—a contribution to urban ecology in Spain. Landscape and Urban Planning 59(4): 203-216.

Dear, M. and N. Dahmann. 2011. Urban politics and the Los Angeles school of urbanism. In Judd, D.R. and D. Simpson (eds.). The city, revisited: urban theory from Chicago, Los Angeles, and New York. Minneapolis: University of Minnesota Press. Pp. 65-78.

Kailash Ecovillage. 2017. Depave 2015. http://www.kailashecovillage.org/depave-2015/ Accessed 5/31/2019.

Kailash Ecovillage. 2017. Gardens. http://www.kailashecovillage.org/gardens/ Accessed 5/31/2019. 
Kailash Ecovillage. 2017. Kailash Ecovillage. https://www.kailashecovillage.org/ Accessed 5/31/2019.

Drake, L. and L.J. Lawson. 2014. Validating verdancy or vacancy? The relationship of community gardens and vacant lands in the U.S. Cities 40 (October): 133-142.

Duany, A., E. Plater-Zyberk and J. Speck. 2000. Suburban nation: the rise of sprawl and the decline of the American dream. New York: North Point Press.

E. Amitai. 1996. The new golden rule. New York: Basic Books.

E. Amitai. 2000. Creating good communities and good societies. Contemporary Sociology 29(1): 188-195.

Fellowship for Intentional Community. N.D. About the Fellowship for Intentional Community.

Foo, K., D. Martin, C. Wool and C. Polsky. 2013. The production of urban vacant land: relational placemaking in Boston, MA neighborhoods. Cities 35 (December): 156-163.

Foster, J. 2014. Hiding in plain view: vacancy and prospect in Paris' Petite Ceinture. Cities 40 (October): 124132.

From garden to table. n.d. Songaia Cohousing Community. Accessed 12/11/2017.

Fuller, R.A., K.N. Irvine, P. Devine-Wright, P.H. Warren and K.J. Gaston. 2007. Psychological benefits of greenspace increase with biodiversity. Biology Letters 3(4): 390-394.

Gandy, M. 2003. Concrete and clay: reworking nature in New York City. Cambridge, MA: The MIT Press.

Garde, A.M. 1999. Marginal spaces in the urban landscape: regulated margins or incidental open spaces? Journal of Planning Education and Research 18(3): 200-210.

Garde, A.M. 2004. New Urbanism as sustainable growth?: a supply side story and its implications for public policy. Journal of Planning Education and Research 24(2): 154-170.

Garvin, E.C., C.C. Cannuscio and C.C. Branas. 2013. Greening vacant lots to reduce violent crime: a randomised controlled trial. Injury Prevention 19(3): 198-203.

Gillham, O. 2002. The limitless city: a primer on the urban sprawl debate. Washington, D.C.: Island Press.

Girardet, H. 2014. Creating regenerative cities. New York: Routledge.

Google Maps. 2017.

https://www.google.com/maps/place/22525+39th+Ave+SE,+Bothell,+WA+98021/@47.7930368,-

122.1810077,526m/data=!3m1!1e3!4m5!3m4!1s0x54900ee00866b9e5:0xa661d10c10363fc7!8m2!3d4 7.7930368!4d-122.178819.

Grant, J. and K. Perrott. 2009. Producing diversity in a New Urbanism community: policy and practice. Town Planning Review 80(3): 267-289.

Gray-O'Connor, J. 2009. Solutions in search of problems: the construction of urban inequality in 'smart growth' discourse. Berkeley Journal of Sociology 53: 89-123.

Haglund, N. 2016a. Bothell village residents concerned about new developments. Everett Herald, July 21.

Haglund, N. 2016b. County affirms development near eco-friendly community. Everett Herald, September 1.

Haglund, N. 2017. Sustainable Bothell community compromises with developers. Everett Herald, June 4.

Haluza-DeLay, R. and R. Berezan. 2013. Permaculture in the city: ecological habitus and the distributed ecovillage. In Lockyer, J. and J.R. Veteto (eds.). Environmental anthropology engaging Ecotopia: bioregionalism, permaculture, and ecovillages. New York: Berghahn.

Harcourt, B.E. 2001. Illusion of order: the false promise of broken windows policing. Cambridge, MA: Harvard University Press.

Hemenway, T. 2015. The permaculture city: regenerative design for urban, suburban, and town resilience. White River Junction, VT: Chelsea Green Publishing.

Henfrey, T. and L. Ford 2018. Permacultures of transformation: steps to a cultural ecology of environmental action. Journal of Political Ecology 25: 104-119.

Heynen, N. 2006. The political ecology of uneven urban green space: the impact of political economy on race and ethnicity in producing environmental inequality in Milwaukee. Urban Affairs Review 42(1): 3-25. 
Hillsdon, M., J. Panter, C. Foster and A. Jones. 2006. The relationship between access and quality of urban green space with population physical activity. Public Health 120(12): 1127-1132.

Hollander, J.B., K. Pallagst, T. Schwarz and F.J. Popper. 2009. Planning shrinking cities. Progress in Planning 7(4): 223-232.

Jacke, D. and E. Toensmeier. 2005. Edible forest gardens. vol. 1: ecological vision and theory for temperate climate permaculture. White River Junction, VT: Chelsea Green Publishing.

Jackson, K.T. 1985. Crabgrass frontier: the suburbanization of the United States. New York: Oxford University Press.

Jacobs, J. 1992. The death and life of great American cities. New York: Vintage Books.

Kelman, A. 2003. A river and its city: the nature of landscape in New Orleans. Berkeley: University of California Press.

Kennedy, S.H. 2008. The garden. Oscilloscope.

Kim, G., P.A. Miller and D.J. Nowak. 2015. Assessing urban vacant land ecosystem services: urban vacant land as green infrastructure in the city of Roanoke, Virginia. Urban Forestry \& Urban Greening 14(3): 519526.

Kim, J. and R. Kaplan. 2004. Physical and psychological factors in sense of community: New Urbanist Kentlands and nearby Orchard Village. Environment and Behavior 36(3): 313-340.

Knaap, G. and E. Talen. 2005. New Urbanism and smart growth: a few words from the academy. International Regional Science Review 28(2): 107-118.

Kolko, J. 2015. How suburban are big American cities? FiveThirtyEight, May 21, 2015.

Kopp, J.J. 2009. Eden within Eden: Oregon's utopian heritage. Corvallis, OR: Oregon State University Press.

Kunstler, J.H. 1993. The geography of nowhere: the rise and decline of America's man-made landscape. New York: Simon \& Schuster.

Kushner, J.A. 2002. Smart growth, New Urbanism and diversity: progressive planning movements in America and their impact on poor and minority ethnic populations. UCLA Journal of Environmental Law and Policy 21: 45-74.

Land. n.d. Songaia Cohousing Community. Accessed December 11, 2017. http://www.songaia.com/land.html

Langegger, S. 2013. Emergent public space: sustaining Chicano culture in North Denver. Cities 35 (December): 26-32.

Lanphear, F. 2001. The 'stuff of community' - economics, culture and governance. Communities 113 (Winter): 15-18.

Lanphear, F. 2014. Songaia, an unfolding dream: the story of a community's journey into being. Bothell, WA: Songaia Press.

Lanphear, N. 2002. Simple gifts and good food: how the fabulous food folks save money at Songaia. Communities 116 (Fall): 50.

Lanphear, N. 2003. Song and story at Songaia. Communities 121 (Winter): 44-46.

Lawson, L. 2009. The precarious nature of semi-public space: community garden appeal, complacency and implications for sustaining user-initiated places. In Orvelli, M. and J.L. Meikle (eds.). Public space and the ideology of place in American culture New York: Rodopi. Pp. 199-218.

LeBlanc, R.M. 2017. Designing a beautifully poor public: postgrowth community in Italy and Japan. Journal of Political Ecology 24: 449-461.

Levitt, L. 2017. An expansive vision of place: lessons from a small urban garden. Senior Comprehensive Exercise, Northfield, MN: Carleton College.

Lockyer, J. 2017. Community, commons, and degrowth at Dancing Rabbit Ecovillage. Journal of Political Ecology 24: 519-542.

Lockyer, J. and J.R. Veteto (eds.). 2013. Environmental anthropology engaging Ecotopia: bioregionalism, permaculture, and ecovillages. New York: Berghahn. $\underline{\text { intro }}$ 
Mäkinen, K. and L. Tyrväinen. 2008. Teenage experiences of public green spaces in suburban Helsinki. Urban Forestry and Urban Greening 7(4): 277-289.

Manzella, J.C. 2010. Common purse, uncommon future: the long, strange trip of communes and other intentional communities. Santa Barbara, CA: Praeger.

McClintock, N. 2008. From industrial garden to food desert: unearthing the root structure of urban agriculture in Oakland, California. ISSC Working Paper 32. UC Berkeley: Institute for the Study of Social Change.

McDonough, W. and M. Braungart. 2002. Buildings like trees, cities like forests.

Mollison, B. and D. Holmgren. 1982. Permaculture one: a perennial agriculture for human settlements. 2nd ed. Maryborough, Australia: Tagari.

Moore, S. 2006. Forgotten roots of the green city: subsistence gardening in Columbus, Ohio, 1900-1940. Urban Geography 27(2): 174-192.

Morris, F.A. 2012. When science goes feral. NJAS - Wageningen Journal of Life Sciences 59(1-2): 7-9.

Nash, R.F. 2001. Wilderness and the American mind. 4th ed. New Haven: Yale University Press.

Nassauer, J.I., Z. Wang and E. Dayrell. 2009. What will the neighbors think? cultural norms and ecological design. Landscape and Urban Planning 92(3-4): 282-292.

Nations, J.D. 2006. The Maya tropical forest: people, parks, and ancient cities. Austin: University of Texas Press.

Németh, J. and J. Langhorst. 2014. Rethinking urban transformation: temporary uses for vacant land. Cities 40 (October): 143-150.

Parkview Ridge. 2017. D.R. Horton: America's Builder.

Paulson, S. 2017. Degrowth: culture, power and change. Journal of Political Ecology 24: 425-448.

Pearsall, H. and S. Lucas. 2014. Vacant land: the new urban green? Cities 40 (October): 121-123.

Permaculture ethics. n.d. Permacultureprinciples.Com. Accessed December 9, 2017.

Pickerill, J.M. 2015. Building the commons in eco-communities. In Kirwan, S., L. Dawney and J. Brigstocke (eds.). Space, power, and the commons: the struggle for alternative futures. London: Routledge. Pp. 3154.

Pickerill, J.M. 2013. Permaculture in practice: low impact development in Britain. In Lockyer, J. and J.R. Veteto (eds.). Environmental anthropology engaging Ecotopia: bioregionalism, permaculture, and ecovillages. New York: Berghahn. Pp. 180-194.

Przybylinski, S. 2015. The right to dream: assessing the spatiality of a homeless rest site in Portland, Oregon. MA in Geography. Portland: Portland State University.

Pyatok, M. 2000. Comment on Charles C. Bohl's "New Urbanism and the city: potential applications and implications for distressed inner-city neighborhoods - the politics of design: the New Urbanists vs. the grass roots." Housing Policy Debate 11(4): 803-814.

Pyle, R.M. 2002. Eden in a vacant lot: special places, species, and kids in the neighborhood of life. In P.H. Kahn Jr. and S.R. Kellert (eds.). Children and nature: psychological, sociocultural, and evolutionary investigations. Cambridge, MA: The MIT Press. Pp. 305-328.

Randall, B. 2013. Culture, permaculture, and experimental anthropology in the Houston foodshed. In Lockyer, J. and J.R. Veteto (eds.). Environmental anthropology engaging Ecotopia: bioregionalism, permaculture, and ecovillages. New York: Berghahn.

Redfield, R. 1960. The little community and peasant, society, and culture. Chicago: University of Chicago Press.

Robbins, P. 2007. Lawn people: how grasses, weeds, and chemicals make us who we are. Philadelphia: Temple University Press.

Rome, A. 2001. The bulldozer in the countryside: suburban sprawl and the rise of American environmentalism. Cambridge: Cambridge University Press. 
Rosen, M. and J.A. Tarr. 1994. The importance of an urban perspective in environmental history. Journal of Urban History 20(3): 299-310.

Saldivar-Tanaka, L. and M.E. Krasny. 2004. Culturing community development, neighborhood open space, and civic agriculture: the case of Latino community gardens in New York City. Agriculture and Human Values 21(4): 399-412.

Scott, J.C. 2008. Seeing like a state: how certain schemes to improve the human condition have failed. New Haven: Yale University Press.

Southworth, M. 2001. Wastelands in the evolving metropolis. ISSC Working Paper 1. UC Berkeley: Institute for the Study of Social Change.

Spirn, A.W. 1996. Constructing nature: the legacy of Frederick Law Olmsted. In Cronon, W. (ed.). Uncommon ground: rethinking the human place in nature. New York: W.W. Norton \& Company.

Squires, G. 2002. Urban sprawl: causes, consequences, and policy responses. Washington, DC: The Urban Institute Press.

Talen, E. 1999. Sense of community and neighbourhood form: an assessment of the social doctrine of New Urbanism. Urban Studies 36(8): 1361-1379.

The Charter of the New Urbanism. n.d. Congress for the New Urbanism. https://www.cnu.org/who-weare/charter-new-urbanism

Till, K.E. 2001. New Urbanism and nature: green marketing and the neotraditional community. Urban Geography 22(3): 220-248.

Tsing, A.L. 2011. Friction: an ethnography of global connection. Princeton: Princeton University Press.

Tsing, A.L. 2012. On nonscalability: the living world is not amenable to precision-nested scales. Common Knowledge 18(3): 505-524.

Tsing, A.L. 2015. The mushroom at the end of the world: on the possibilities of life in capitalist ruins. Princeton: Princeton University Press.

Vessel, M.F. and H.H. Wong. 1987. Natural history of vacant lots. California Natural History Guide 50. Berkeley: University of California Press.

Ward, J.D., P.C. Sutton, A.D. Werner, R. Costanza, S.H. Mohr and C.T. Simmons. 2016. Is decoupling GDP growth from environmental impact possible? PLoS ONE 11(10): 1-14.

Wilk, R. and M.B. Schiffer. 1979. The archaeology of vacant lots in Tucson, Arizona. American Antiquity 44(3): 530-536.

Williams, R. 1975. The country and the city. Oxford: Oxford University Press.

Williams, R. 1983. Keywords: a vocabulary of culture and society. Revised. New York: Oxford University Press.

Wolch, J.R., J. Byrne and J.P. Newell. 2014. Urban green space, public health, and environmental justice: the challenge of making cities 'just green enough.' Landscape and Urban Planning 125 (May): 234-244. 